\title{
Anthropometric and Biochemical Parameters of Rats Treated with a Low-carbohydrate Diet
}

\author{
Ana Paula Pinto ${ }^{1}$, Gisele Massafera ${ }^{1}$, Alceu Afonso Jordao ${ }^{2}$, Telma Maria Braga Costa ${ }^{3, *}$ \\ ${ }^{1}$ Nutrition Course at University of Ribeirão Preto - UNAERP \\ ${ }^{2}$ Division of Nutrition and Metabolism - Department of Internal Medicine, Faculty of Medicine of Ribeirão Preto/USP \\ ${ }^{3}$ Department of Psychology, Faculty of Philosophy, Sciences and Letters of Ribeirão Preto - FFCLRP, University of São Paulo - USP \\ *Correspondence author: tbraga@unaerp.br
}

Copyright $@ 2013$ Horizon Research Publishing All rights reserved.

\begin{abstract}
The aim of this study was to induce obesity in rats and then feed them a carbohydrate-restricted diet and assess its effects on anthropometric and biochemical parameters. Forty-eight weanling male Wistar rats were divided into three groups: Control $(\mathrm{n}=18)$; Experimental 1 $(\mathrm{n}=15)$ and Experimental $2(\mathrm{n}=15)$. The experiment was divided into two phases of 60 days each. For the first 60 days, the Control Group received a control diet and Experimental Groups 1 and 2 received an obesity-inducing diet containing $17 \%$ lipid, $0.5 \%$ cholic acid and $1 \%$ cholesterol. Diet and water were offered ad libitum and the animals were weighed three times a week. Over the final 60 days, Experimental Group 1 started to receive the control diet and Experimental Group 2 started to receive a carbohydrate-restricted diet containing $40 \%$ protein and $50 \%$ lipid. During phase I, the animals of the Experimental Groups showed greater weight gain, hepatic steatosis, increased retroperitoneal and perigonadal tissue and increased total cholesterol and LDL. During phase II, Experimental Group 2 showed a higher weight gain, hepatic steatosis, and higher total and LDL cholesterol values compared to Control and to Experimental Group 1. We conclude that the goal of first phase, which was to induce the rats to obesity through fat diet containing cholesterol and cholic acid was hit because was a increasing body weight, retroperitoneal and perigonadal fat and hepatic steatosis. The carbohydrate-restricted diet was not effective in terms of weight loss, with the presence of hepatic steatosis and increased retroperitoneal and perigonadal tissue
\end{abstract}

Keywords Fatty Liver, Weight Gain, Dr. Atkins' Diet

\section{Introduction}

The world Health Organization (WHO) defines overweight and obesity as excessive fat accumulation that may impair health ${ }^{1}$. The Brazilian Ministry of Health complements this definition by stating that the immediate determinant of excessive fat accumulation is a positive energy balance, defined as the difference between the quantity of energy consumed and the quantity of energy expended to perform vital functions and general activities ${ }^{2}$.

According to the WHO (2011), at least 2.8 million adults die each year due to overweight and obesity. In addition, $44 \%$ of cases of diabetes mellitus, $23 \%$ of ischemic cardiopathy and $7 \%$ to $41 \%$ of all cancers can be attributed to overweight and obesity ${ }^{3}$.

Because of this epidemic of obesity, over the last few years many diets have been offered promising a rapid weight loss with minimal effort, denoted fashionable diets ${ }^{4}$. One of the most famous is the diet proposed by Dr. Robert C. Atkins, which involves a low-calorie ketogenic regimen with carbohydrate restriction and free consumption of lipids and proteins ${ }^{5}$.

The diet consists of four steps: a 14 day period of "induction" during which the intake of carbohydrates must be reduced to less than $20 \mathrm{~g}$ per day, and three periods during which the intake of carbohydrates is progressively increased. According to Atkins, approximately 20 million followers benefit from his diet, obtaining a rapid weight loss, maintenance of weight loss without hunger, good health, and the prevention of cardiovascular diseases ${ }^{5}$.

According to the American Medical Association, lipidand protein-rich diets cause risks such as cardiovascular diseases, cancer, gallstones and hypercholesterolemia. In addition, several followers of these diets have complained of constipation, ketogenic breath, headache, weakness, and diarrhea, possibly explained by the low consumption of fruits, legumes and cereals ${ }^{6}$.

There is no solid evidence supporting the indiscriminate use of diets containing $20 \mathrm{~g}$ or less of carbohydrates for more than 90 days. Although carbohydrate-restricted diets may induce weight loss on a short-term basis, as reported in some studies, it has not been demonstrated thus far that these diets are safe or effective for long-term use ${ }^{7}$.

Today, more than 30 genetic models of animal obesity have been described in the literature. A genetic model is defined as a model in which obesity can be inherited through 
a defect in a single gene or in multiple genes, as is the case for rats with mutations that affect peripheral tissues. However, since today obesity is related to sedentarism and a greater availability and consumption of food, studies have been conducted using the so-called "non-genetic models of obesity", in which obesity is induced by the diet or by chemical and surgical procedures ${ }^{8}$.

In animal studies, the investigators can start with a standard rodent diet (AIN-93) and modify the proportion of macronutrients in order to obtain experimental models that simulate human diseases such as obesity and liver steatosis. For examples, the use of a high-lipid diet can lead to changes in body measurements and to biochemical alterations ${ }^{9}$.

In this respect, several other experimental models have been used, such as the cafeteria diet, which consists of foods such as biscuits, cookies etc. rich in sugar and fat ${ }^{9}$, simulating the intake of these foods by humans.

For studies that require the induction of obesity, a high-fat diet confirms the efficiency of the use of this model, in which rats fed these diets become obese. Thus, in view of the deleterious effects of obesity, it is important to study the metabolic effects and the consequences of the adoption of "popular" diets for weight loss.

\section{Objective}

The general objective of the present study was to assess body measurements and biochemical parameters in rats submitted to a diet with carbohydrate restriction and to assess the possible effects of this diet based on parameters such as food consumption, weight gain curve, physical evaluation (animal size), evaluation of obesity (weight of the perigonadal and retroperitoneal fat), organ weight (brain and liver), quantitative analyses of hepatic lipids, and biochemical determinations of glucose, total cholesterol and its fractions, and triglycerides.

\section{Material and Method}

The study was approved by the Ethics Committee of the University of Ribeirão (protocol: 89/).

The animals were housed in polypropylene cages with stainless steel lid barred. The diet was offered in glass jars with a capacity of $240 \mathrm{ml}$ and troughs of polyethylene, in an environment with constant temperature of $23 \pm 1{ }^{\circ} \mathrm{C}$, light-dark cycle of 12/12 hours with free access to water and food.

Forty-eight male weanling Wistar rats (21 days of age) were used. The animals were divided into 3 groups: Control Group (C), $\mathrm{n}=18$, Experimental 1 (E1), $\mathrm{n}=15$, and Experimental 2 (E2), $\mathrm{n}=15$. Data collection was divided into two phases of 60 days each. During the first 60 days, Group $C$ received a control diet based on the AIN - 93G diet and Groups E1 and E2 received a diet containing 17\% lipid in addition to $0.5 \%$ cholic acid and $1 \%$ cholesterol. During the final 60 days, Group E1 received the control diet and Group E2 the carbohydrate-retsricted diet containing $40 \%$ protein and $50 \%$ lipid. The animals were weighed three times a week and received the diet and water ad libitum. At the end of the experiment they were euthanized, the brain, retroperitoneal and perigonadal adipose tissue and the liver were removed and weighed, and hepatic lipids were analyzed quantitatively determined by the Soxlet method.

Food consumption by the rodents was determined by the food remnants method, with the feeder being weighed before and after diet consumption. The weight gain curve was determined by weighing the animals three times a week and physical evaluation was performed at the end of the experiment by aligning one animal from each group on the bench and measuring its length with a Pesfer ${ }^{\circledR}$ measuring tape. Serum biochemical analyses were also performed, after euthanized a transversal cut was made in the abdomen of the animals by collecting blood and quantifying the colorimetric enzymatic method.

Data analysis was by the mean and standard deviation of the results obtained with a significance level of $p<0.05$ and statistical analysis was by analysis of variance for multifactor ANOVA program Instat Graph.

\section{Results}

Regarding food consumption, it can be seen that during the first 60 days of the Experiment (Phase I), the animals of the Control Group consumed more ration than the animals of the Experimental Groups, and the E2 consumed more ration than E1 (Tab. 1). Although the energy intake (kcal) between groups was nonsignificant.

Table 1. Mean diet consumption (kg) in Control Group, Experimental Group 1 and Experimental Group 2, during Phase I and II of the experiment. $(*) \mathrm{p}<0.05$.

\begin{tabular}{|c|c|c|c|c|c|c|}
\hline $\begin{array}{c}\text { PHASE OF } \\
\text { EXPERIMENT }\end{array}$ & \multicolumn{2}{|c|}{ PHASE I - INDUCTION OF OBESITY } & \multicolumn{3}{|c|}{ PHASE II - ATKINS DIET TEST } \\
\hline Group & Control & E1 & E2 & Control & E1 & E2 \\
\hline Number of animals & 18 & 15 & 15 & 12 & 12 & 12 \\
\hline $\begin{array}{c}\text { Mean ration } \\
\text { consumption (kg) }\end{array}$ & $0.111 \square$ & $0.091 \square$ & $0.095 \square$ & $0.118 \square$ & $0.118 \square$ & $0.071 \square$ \\
\hline Energy Intake (Kcal) & $420 \square$ & $380 \square$ & $400 \square$ & $445 \square$ & $445 \square$ & $430 \square$ \\
\hline
\end{tabular}

Values followed by equal letters did not differ significantly from one another. $\mathrm{p}<0.05$. 
It can be seen that mean diet consumption during the final 60 days (Phase II) did not differ between the Control Group and the E1 since both groups received the same diet. E2 animals consumed a significantly lower amount of ration compared to the other two groups (Tab. 1), although no significant difference was observed between the three groups regarding the amount of energy.

Regarding the mean weight of the animals euthanized in Phase I ( $n=12)$, at 81 days of age, the weight gain curves for the animals of E1 and E2 ( $n=3$, respectively) were significantly higher than that for the Control Group $(n=6)$; but did not differ from one another.

The mean weight gain curve during Phase II, was significantly greater for E2 animals $(n=12)$ compared to Control animals $(n=12)$ and E1 animals $(n=12)$. E1 animals also showed significantly higher values than Control animals $(\mathrm{n}=12)$.

During Phase I (Table 2) there was no significant difference in retroperitoneal or perigondal fat between groups. However. E2 animals had significantly higher values of retroperitoneal fat (Table 2) than Control and E1 animals in Phase II. In addition, these animals also differed significantly from Control and E1 animals during Phase I, especially with significant differences between groups in Phase I and II of the Experiment. However, E1 animals had lower perigonadal fat values compared to Control Group animals in Phase II.

Table 3 shows that in Phase I, there was no significant difference in brain weight, although in Phase II , E2 animals showed significantly lower brain weight than Control animals.

After euthanasia, the animal submitted to Phase I showed differences in liver anatomy visible to the naked eye. The liver of Control Group animals had normal color and anatomy, whereas the liver of the Experimental Groups showed visible hepatic steatosis, as shown in Figure 1. In Phase II, the liver of Control Group animals continued to show normal color and anatomy, the liver of E1 animals showed a reduction of the hepatic steatosis obtained in Phase I, with improved color and anatomy, and E2 animals still showed visible hepatic steatosis (Fig. 1).

The percentage of lipids present in the liver of the rats of each group was obtained by the Soxhlet method in each phase of the Experiment (Table 4). The animals receiving the high-fat diet containing $1 \%$ cholesterol (Phase I) showed a significantly higher percentage of lipids in the liver compared to the Control Group (Table 4). In Phase II (Table 4), E2 animals showed a higher percentage of hepatic lipids than both Control animals and E1 animals. In Phase I, E1 and E2 did not differ significantly from E2 in Phase II.

In Phase I, control animals did not show total cholesterol values above reference levels (Table 5), and E1 animals (Phase I) showed a significant difference in total cholesterol values compared to all other groups in Phase II of the Experiment. The values of the LDL fraction of cholesterol were much higher for E1 and E2 animals in Phase I, but were reduced in Phase II.

Table 2. Mean weight of retroperitoneal and perigonadal weight (g) during Phases I and II of the experiment (animals of the Control and Experimental 1 and 2 Groups).

\begin{tabular}{|c|c|c|c|c|c|c|}
\hline $\begin{array}{c}\text { PHASE OF } \\
\text { EXPERIMENT }\end{array}$ & \multicolumn{2}{|c|}{ PHASE I - INDUCTION OF OBESITY } & \multicolumn{3}{c|}{ PHASE II - ATKINS DIET TEST } \\
\hline Group & Control & E1 & E2 & Control & E1 & E2 \\
\hline Number of animals & 6 & 3 & 3 & 12 & 12 & 12 \\
\hline Retroperitoneal fat (g) & $1.0 \pm 0 \square$ & $3.67 \pm 2.08 \square$ & $2.33 \pm 0.58 \square$ & $3.75 \pm 1.06 \square$ & $3.50 \pm 1.51 \square$ & $11.42 \pm 3.34 \square$ \\
\hline Perigonadal fat (g) & $4.17 \pm 0.98 \square$ & $6.33 \pm 2.31 \square$ & $4.33 \pm 1.15 \square$ & $8.5 \pm 2.02 \square$ & $5.92 \pm 1.44 \square$ & $12.58 \pm 2.87 \square$ \\
\hline
\end{tabular}

Values reported as mean \pm standard deviation .

Values followed by equal letters did not differ significantly from one another. $\mathrm{p}<0.05$.

Table 3. The quantity of animal brain in Percent (\%) brain in Control and Experimental 1 and 2 Groups during Phases I and II (\% of body weight).

\begin{tabular}{|c|c|c|c|c|c|c|}
\hline $\begin{array}{c}\text { PHASE OF } \\
\text { EXPERIMENT }\end{array}$ & \multicolumn{2}{|c|}{ PHASE I - INDUCTION OF OBESITY } & \multicolumn{3}{c|}{ PHASE II - ATKINS DIET TEST } \\
\hline Group & Control & E1 & E2 & Control & E1 & E2 \\
\hline $\begin{array}{c}\text { Number of } \\
\text { animals }\end{array}$ & 6 & 3 & 3 & 12 & 12 & 12 \\
\hline$\%$ & $0.41 \pm 0.15 \square$ & $0.3 \pm 0.03 \square$ & $0.44 \pm 0.05 \square$ & $0.47 \pm 0.15 \square$ & $0.32 \pm 0.12 \square$ & $0.27 \pm 0.17 \square$ \\
\hline
\end{tabular}

Values reported as mean \pm standard deviation .

Values followed by equal letters did not differ significantly from one another. $\mathrm{p}<0.05$. 


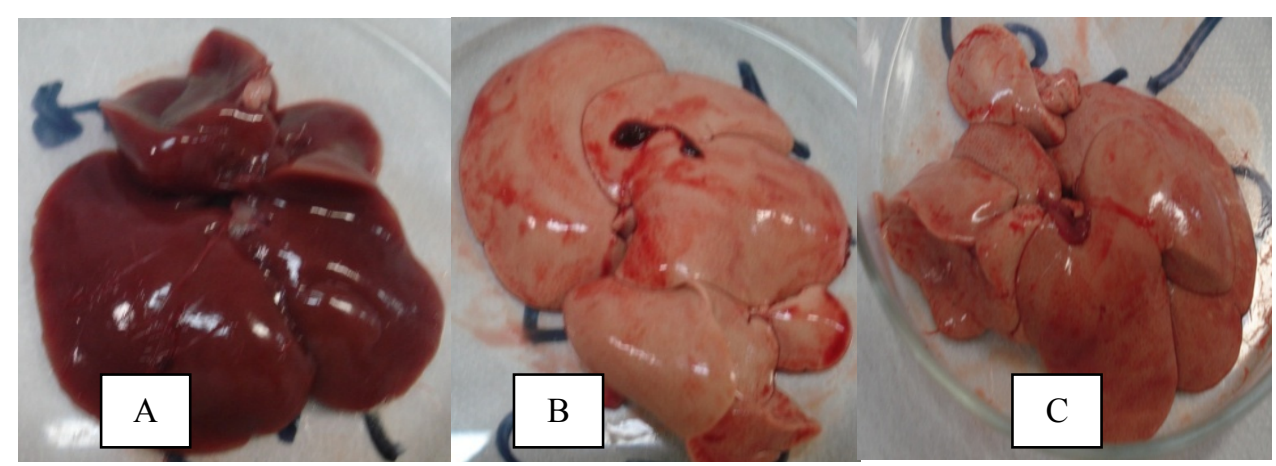

Figure 1. Liver of an animal of the Control Group with normal color and anatomy (A) and livers of the E1 (B) and E2 (C) Groups with hepatic in Phase I of the Experiment, Ribeirão Preto, 2012.
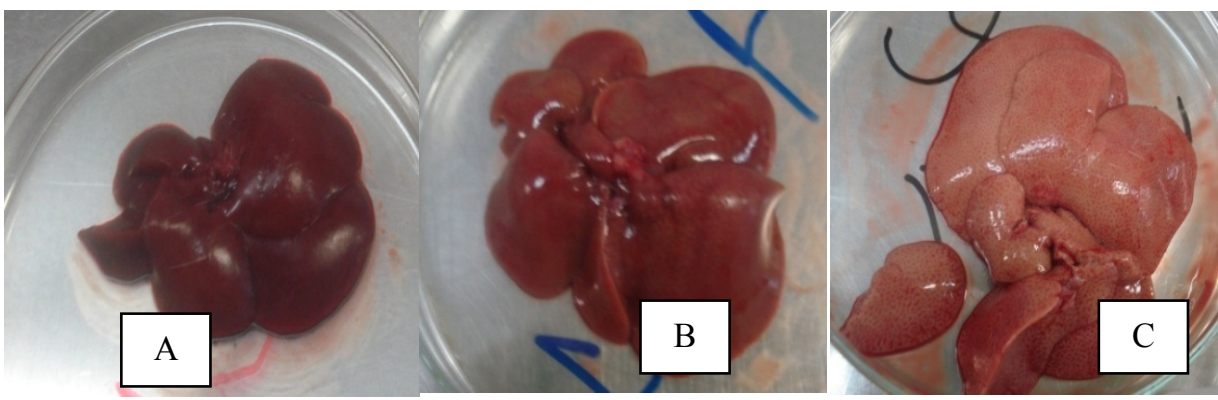

Figure 2. Liver of an animal of the Control Group with normal color and anatomy (A), liver of an animal of Experimental Group 1 with decreased hepatic steatosis (B), and liver of an animal of Experimental Group 2 with hepatic steatosis (C), in Phase II - Atkins Diet Test (60 days), Ribeirão Preto, 2012.

Table 4. The quantity of lipids (as \% of tissue dry) in liver during Phases I and II of the Experiment (animals of the Control and Experimental 1 and 2 Groups).

\begin{tabular}{|c|c|c|c|c|c|c|}
\hline $\begin{array}{c}\text { PHASE OF } \\
\text { EXPERIMENT }\end{array}$ & \multicolumn{2}{|c|}{ PHASE I - INDUCTION OF OBESITY } & \multicolumn{3}{c|}{ PHASE II - ATKINS DIET TEST } \\
\hline Group & Control & E1 & E2 & Control & E1 & E2 \\
\hline $\begin{array}{c}\text { Number of } \\
\text { animals }\end{array}$ & 6 & 3 & 3 & 12 & 12 & 12 \\
\hline$\%$ Lipids & $6.27 \pm 2.81$ & $19.47 \pm 8.80 \square$ & $23.65 \pm 2.74 \square$ & $3.86 \pm 1.38 \square$ & $9.03 \pm 6.22 \square$ & $25.68 \pm 5.75$ \\
\hline
\end{tabular}

Values reported as mean \pm standard deviation .

Values followed by equal letters did not differ significantly from one another .

$\mathrm{p}<0.05$.

Table 5. Biochemical parameters of blood serum during Phases I and II of the experiment (animals of the Control and Experimental 1 and 2 Groups)

\begin{tabular}{|c|c|c|c|c|c|c|}
\hline $\begin{array}{c}\text { PHASE OF } \\
\text { FXPERIMFNT }\end{array}$ & \multicolumn{3}{|c|}{ PHASE I - INDUCTION OF OBESITY } & \multicolumn{3}{|c|}{ PHASE II - ATKINS DIET TEST } \\
\hline Group & Control & E1 & E2 & Control & E1 & E2 \\
\hline Number of animals & 6 & 3 & 3 & 12 & 12 & 12 \\
\hline Glucose (mg/dl) & $\begin{array}{l}142.5 \pm \\
16.91 \quad \square \square\end{array}$ & $\begin{array}{l}163.3 \pm \\
10.21\end{array}$ & $\begin{array}{l}167.0 \pm \\
17.52\end{array}$ & $\begin{array}{l}111.64 \pm \\
20.81 \square\end{array}$ & $\begin{array}{l}113.09 \pm \\
21.74 \quad \square\end{array}$ & $\begin{array}{l}131.58 \pm \\
22.93 \quad \square \square\end{array}$ \\
\hline $\begin{array}{l}\text { Total cholesterol } \\
(\mathrm{mg} / \mathrm{dl})\end{array}$ & $\begin{array}{l}62.0 \pm \\
3.35\end{array}$ & $\begin{array}{l}184.0 \pm \\
110.73 \square\end{array}$ & $\begin{array}{l}129.7 \pm \\
92.20\end{array}$ & $\begin{array}{l}76.69 \pm \\
14.70 \quad \square\end{array}$ & $\begin{array}{l}78.64 \pm \\
15.45 \quad \square\end{array}$ & $\begin{array}{l}93.25 \pm \\
16.38 \quad \square\end{array}$ \\
\hline $\begin{array}{l}\text { HDL cholesterol } \\
(\mathrm{mg} / \mathrm{dl})\end{array}$ & $\begin{array}{l}36.37 \pm \\
4.11 \quad \square\end{array}$ & \begin{tabular}{|l|l|}
$39.17 \pm$ \\
$3.92 \quad \square \square$
\end{tabular} & $\begin{array}{ll}35.13 \pm \\
7.30 \quad \square \square\end{array}$ & \begin{tabular}{|l|}
$42.58 \pm$ \\
10.36
\end{tabular} & $\begin{array}{l}46.19 \pm \\
8.22 \quad \square \square\end{array}$ & $\begin{array}{l}49.91 \pm \\
9.88 \quad \square\end{array}$ \\
\hline $\begin{array}{l}\text { LDL cholesterol } \\
(\mathrm{mg} / \mathrm{dl})\end{array}$ & $\begin{array}{l}15.17 \pm \\
2.86 \quad \square\end{array}$ & $\begin{array}{l}136.33 \pm \\
109.2 \square\end{array}$ & $\begin{array}{l}82.33 \pm \\
87.88\end{array}$ & $\begin{array}{l}14.69 \pm \\
8.13 \quad \square\end{array}$ & $\begin{array}{l}17.53 \pm \\
10.06\end{array}$ & $\begin{array}{l}28.75 \pm \\
8.21 \quad \square\end{array}$ \\
\hline $\begin{array}{l}\text { VLDL cholesterol } \\
(\mathrm{mg} / \mathrm{dl})\end{array}$ & $\begin{array}{l}10.47 \pm \\
2.28 \quad \square\end{array}$ & $8.60 \pm 4.50$ & $\begin{array}{l}12.07 \pm \\
4.04 \quad \square\end{array}$ & $\begin{array}{l}19.56 \pm \\
8.60 \quad \square\end{array}$ & $\begin{array}{l}15.04 \pm \\
4.40 \quad \square\end{array}$ & $\begin{array}{l}14.58 \pm \\
4.39 \quad \square\end{array}$ \\
\hline $\begin{array}{c}\text { TGs } \\
(\mathrm{mg} / \mathrm{dl})\end{array}$ & $\begin{array}{l}52.33 \pm \\
11.40 \quad \square\end{array}$ & $\begin{array}{l}43.0 \pm \\
22.52 \square\end{array}$ & \begin{tabular}{|l|}
$60.33 \pm$ \\
20.21
\end{tabular} & $\begin{array}{l}97.82 \pm \\
42.98 \quad \square\end{array}$ & \begin{tabular}{|l|}
$75.18 \pm$ \\
22.01
\end{tabular} & $\begin{array}{ll}72.92 \pm & \\
21.97 \quad \square \square\end{array}$ \\
\hline
\end{tabular}

Values reported as mean \pm standard deviation.

Values followed by equal letters did not differ significantly from one another. $\mathrm{p}<0.05$. 


\section{Discussion}

The present study showed that rats fed a carbohydrate-restricted diet consumed smaller amounts of food in both phases of the experiment compared to the Control Group, although there was no difference in energy intake. These facts were also detected in the study by Picchi et al. ${ }^{9}$ in which experimental animals that received a high-fat diet showed a smaller mean diet consumption than control animals, although both groups consumed the same total amount of energy. Angéloco et al. ${ }^{10}$ also observed that animals fed a high-fat diet consumed significantly less ration (g/week) than control animals although there was no difference between groups in energy intake (kcal/week).

According to Nascimento et al. ${ }^{11}$, high-fat diets cause less satisfaction and consequently a high food intake, also known as hyperphagia. However, this was not observed in their study, in which the group receiving the high-fat diet consumed less food, a fact explained by the high concentration of serum leptin. This would also explain the lower diet consumption of E2 animals of the present study, since in Phase II they received a carbohydrate-restricted diet containing large amounts of lipids and proteins. Another explanation could be that, in the short term, the low-carbohydrate diet may act on central appetite controllers. The satiety reported by the followers of this diet is explained by the increase in ketone bodies and in serotonin levels. Serotonin has a receptor in the hypothalamus with an anorexigenic effect, which may promote a reduced food consumption.

In Phase I, the Experimental groups did not differ significantly in wheight gain from one another, possibly because they had received the same diet during the first 60 days. These results agree with those reported by Duarte et al. ${ }^{12}$ in a study in which rats submitted to a high-calorie diet for a prolonged period of time also showed a greater weight gain rate compared to control rats. In contrast, in Phase II, E2 animals showed greater weight gain than Control and E1 animals. These results agree with those reported by Borba ${ }^{13}$ in a study in which the experimental group receiving a high-fat and protein diet gained more weight than control. Similar results were reported by $\mathrm{Pini}^{14}$, in a study in which animals receiving a high-fat diet had a greater body weight at 77 days of life than control animals. However, these results do not support the proposal of Dr. Atkins, who stated that his diet induced a rapid weight loss. On the other hand, some studies have shown that individuals consuming a low-carbohydrate diet lost more weight than individuals consuming a low-fat diet ${ }^{15,16}$.

As shown in Table 2, there was no significant difference between groups in retroperitoneal or perigonadal fat in Phase I. This is in contrast to other studies, such as that by Estadella et al. ${ }^{17}$, in which rats submitted to a high-fat diet starting at three weeks of age showed an increase in the amount of retroperitoneal and epidydimal adipose tissue. In the present study, the significant increase of these tissues in Phase II in E2 animals demonstrated that the low-carbohydrate diet led to this increase, in contrast to E1, which showed a reduction of perigonadal fat compared to the Control Group in the same phase when its diet was changed to a control diet, demonstrating the efficacy of a balanced diet.

According to Borba ${ }^{13}$, a high-fat and high-protein diet with carbohydrate restriction would lead to a reduction of the animals' brain since carbohydrate is the major energy nutrient for brain tissue. This was demonstrated in the present study, in which the animals receiving a low-carbohydrate diet had a smaller brain mass than the Control Group.

In agreement with the present study, regarding the quantitative analysis of hepatic lipids, Leonardi et al. ${ }^{18}$ observed that rats receiving a high-fat diet and rats receiving a high-fat and high-protein diet had higher hepatic lipid values compared to control. This occurs because the lipid concentration in the hepatocytes is regulated by cellular enzymes involved in synthesis and oxidation, with a consequent elimination of lipids from the liver. When fat enters the system due to an increased intake of fatty acids or due to their increased synthesis exceeding the capacity for oxidation, hepatic steatosis occurs.

In contrast, in Phase II (Table 4), E2 animals showed a higher percentage of hepatic lipids than the animals of the Control Group and of E1. This was probably due to the high-fat and high-protein diet offered to E2 rats, which induces hepatic steatosis. Also, in Phase I, E1 and E2 animals did not differ significantly from E2 animals in Phase II, because both received diets with high lipid concentrations leading to hepatic steatosis. This fact was also confirmed by the results for E1 in the two phases of the experiment, since there was a significant reduction of hepatic steatosis with the reestablishment of a balanced diet.

Analysis of blood serum biochemical indices revealed that in Phase I, E1 animals had much higher LDL cholesterol levels, although these levels were reduced in both groups during Phase II, showing that the increase in LDL cholesterol was due to the obesity-inducing diet, which contained $1 \%$ cholesterol, rather than only to a high-fat diet.

Thus, we conclude that Phase I- can be considered to be an efficient experimental model since the Experimental Groups showed large quantities of retroperitoneal and perigonadal fat, hepatic steatosis, weight gain, and increased levels of total cholesterol and of its LDL fraction in blood serum.

The carbohydrate-restricted diet offered to E2 animals during Phase II, was not able to reverse the body measurements and biochemical changes detected, with these animals showing a greater weight, hepatic steatosis, large amounts of retroperitoneal and perigonadal fat, and increased levels of total cholesterol and of its LDL fraction in blood serum.

On this basis, in the present experimental model the use of a carbohydrate-restricted diet was not effective for the treatment of changes induced by a high-fat diet. 


\section{REFERENCES}

[1] WHO - ORGANIZAÇÃO MUNDIAL DE SAÚDE. Obesity and Overweight. Geneva, 2011, n.311. Disponível em: http://www.who.int/mediacentre/factsheets/fs311/en/>. Acesso em: Agosto 2011.

[2] BRASIL. Obesidade. Cadernos de Atenção Básica, Brasília DF, n. ${ }^{\circ}$ 12, p. $08-110,2006$.

[3] WHO - ORGANIZAÇÃO MUNDIAL DE SAÚDE. Obesity: preventing and managing the global epidemic. Geneva, 1998, n.894. Disponívelem: >http://www.who.int/nutrition/publica tions/obesity/WHO_TRS_894/en/>. Acesso em: Agosto 2011.

[4] BETONI, F; ZANARDO, V.P.S; CENI, G.C. Avaliação de utilização de dietas da moda por pacientes de um ambulatório de especialidades em nutrição e suas implicações no metabolismo. ConScientiae Saúde, v. 3, p. 430 - 440, 2010.

[5] ATKINS, R.C. A nova dieta revolucionária do Dr. Atkins. 14. ed. Rio de janeiro: Records, 2004. Disponível em: $<$ http://www.scribd.com/doc/9882891/A-Nova-Dieta-Revolu cionaria-Do-Dr-Atkins-Robert-c-Atkins $>$. Acesso em: setembro 2011.

[6] AMERICAN MEDICAL ASSOCIATION. A Critique of Low-Carbohydrate Ketogenic Weight Reduction Regimens: A Review of Dr. Atkins' Diet. Revolution Journal of the American Medical Association, v. 224, p.1415, 1974. Disponível em: $<$ http://www.atkinsexposed.org/atkins/75/american_medical _association.htm>. Acesso em: outubro 2011.

[7] BRAVATA, D.M.; SANDERS, L.; HUANG, J.; KRUMHOLZ, H.M.; OLKIN, I.; GARDNE BRAVATA, D. M. Efficacy and safety of low-carbohydrate diets: a systematic review. Journal of the American Medical Association, v. 289, n. 14, p.1837-50, 2003.

[8] PEREIRA, L. O; FRANCISCHI, R. P. DE; LANCHA JR, A. H. Obesidade: Hábitos Nutricionais, Sedentarismo e Resistência à Insulina. Arq Bras Endocrinolo Metab, v. 47, n.2, p. $111-127$, abril 2003.

[9] PICCHI, M.G.; MATTOS, A.M.; BARBOSA, M.R.; DUARTE, C.P.; GANDINI, M.A.; PORTARI, G.V.; JORDÃO, A.A. A high-fat diet as a model of fatty liver disease in rats. Acta Cirúrgica Brasileira, v. 26, p. 25-30, 2011.

[10] ANGÉLOCO, L.R.N; DEMINICI, R; LATARO, R.C;
JORDÃO, A.A. Bioelectrical impedance analysis and anthropometry for the determination of body composition in rats: effects of high-fat and high-sucrose diets. Rev Nut. Campinas, v.5, n.3, p.331-339, maio/jun 2012.

[11] NASCIMENTO, A.F; SUGIZAKI, M.M; LEOPOLDO, A.S; LIMA-LEOPOLDO, A.P; LUVIZOTTO, R.A.M; NOGUEIRA, C.R; CICOGNA, A.C. A Hipercaloric Pellet-Diet Cycle Induces Obesity and Co-Morbidities in Wistar Rats. Arq Bras Endocrinol Metab, v. 52, n.6, p. 968973, 2008.

[12] DUARTE, A. C. G. DE O; FONSECA, D. F; MANZONI, M. S. J; SOAVE, C. F; SENE - FIORESE, M; DÂMASO, A. R; CHEIK, N. C. Dieta hiperlipídica e capacidade secretóriade insulina em ratos. Rev Nutr, Campinas, v. 19, n. 3, p. 341 348, maio/jun 2006.

[13] BORBA, A. J. Efeito da dieta hiperlipídico-protéica no metabolismo de ratos wistar adultos. 2008, 65f. Dissertação (Mestrado) - Programa de Pós-graduação em Patologia, Universidade Federal do Triângulo Mineiro, Uberaba, 2008.

[14] PINI, R. T. B. Efeitos da obesidade sobre comportamentos de ansiedade, depressão, aprendizagem e memória em rato (Rattus novergicus). 2012, 100f. Dissertação (Mestrado) Programa de Pós Graduação em Psicobiologia, Universidade de São Paulo, Ribeirão Preto, 2012.

[15] FOSTER, G. D; WYATT, H. R; HILL, J.O; MCGUCKIN, B.G; BRILL, C; MOHAMMED, B.S; SZAPARY, P.O; RADER, D.J; EDMAN, J.S; KLEIN, S. A Randomized Trial of a Low-Carbohydrate Diet for Obesity. N Engl J Med, v. 348 , p. $2082-2090,2003$.

[16] SAMAHA, F.F; IQBAL, N; SESHADRI, P; CHICANO, K. L; DAILY, D. A; MCGRORY, J; WILLIAMS, M; GRACELY, E.J; STERN, L. A Low-Carbohydrate as Compared with a Low-Fat Diet in Severe Obesity. N Engl J Med, v. 348, p. $2074-2081,2003$.

[17] ESTADELlA, D; OYAMA, L. M.; DÂMASO, A. R.; RIBEIRO, E. B; DO NASCIMENTO, C. M. O. Effect of Palatable Hyperlipidic Diet on Lipid Metabolism of Sedentary and Exercised Rats. Nutrition, v. 20, n.2, p. $218-$ 224, 2004.

[18] LEONARDI, D.S; FERES M.B.C.; PORTARI, G.V; ZANUTO, M.E; ZUCOLOTO, S; JORDAO, A.A. Evaluation of different types of diet in the promotion of hepatic steatosis in rat. Experimental and Clinical Endocrinology \& Diabetes, v. 118, p. 724-729, 2010. 